\title{
Scanning electron microscope study of the native British willows
}

\section{Ruth Hollands}

Royal Botanic Garden, Edinburgh EH3 5LR, U.K.

Fourteen true species of willow native to the British Isles, three in subgenus Chamaetia and the rest arborescent, were studied using fresh material from the Royal Botanic Garden, Edinburgh, and its specialist gardens at Dawyck Arboretum and the Younger Botanic Garden, Benmore. For the remaining six species (and for comparison with the fresh material) herbarium specimens were used. The fresh material was freeze-dried and then both fresh and herbarium material sputter coated in gold/palladium. Pollen, stomata, laminal waxes and the hairs on petiole, seed capsule and abaxial surface of the lamina were examined. The following general results were found.

(a) The pollen (all 3-colpate, reticulate grains) have some slight, but notable, differences. (b) The stomata (all linear, ellipsoid in shape and generally raised rather than sunken) showed little variation between species. (c) Laminal waxes, when present, also appeared very similar between the species. (d) The hairs on all parts examined, and between each species, differed very little, all were simple, 5-13 $\mu$ wide, with some degree of longitudinal ridging, and the tips more or less pointed.

The results obtained, show general uniformity of characters and more detailed studies are necessary. No taxonomic conclusions could be drawn from the information gathered but from this study there appeared to be no detectable differences when using fresh or herbarium material.

\section{Selection and breeding of willows in Sweden}

\section{Stig Larsson}

Svalöf AB, S-268 00 Svalöv, Sweden

A breeding programme of willows for short rotation biomass production was started at Svalöf AB in 1987. The aim of this programme is to produce clones of Salix with higher biomass production, rapid juvenile growth and a good resistance to pests, diseases, in particular leaf-rust and frost. At present, about 3000 new clones are produced every year in the crossing programme.

The acreage of Salix is rapidly increasing in Sweden. The purpose is to produce an alternative source of energy and also to provide an alternative land-use for farmers. Sweden, too, has a problem of agricultural surpluses. The need for new better clones is for that reason very urgent.

Three promising clones, Sv 870082 , Sv 870083 and Sv 870148 have been selected at Svalöf AB and are already under production for marketing 1993. These clones have been tested in yield trials at five places in Sweden. New clones will be protected according to the rules of the 'International Union for the protection of new varieties of plants' (UPOV). New selected clones are being tested in field trials in the U.K. through Svalöf AB's partner in the U.K. 